\title{
Distribution of hepatitis $C$ virus genotypes among injecting drug users in Lebanon
}

\author{
Ziyad Mahfoud ${ }^{1}$, Kassem Kassak², Khalil Kreidieh³, Sarah Shamra ${ }^{3}$ and Sami Ramia*3
}

\begin{abstract}
Background: The aim of this study is to determine the prevalence of anti-HCV among injecting drug users (IDUs) in Lebanon, to establish the current prevalence of HCV genotypes in this population and to determine whether demographic characteristics and behavioral variables differ between participants who were HCV-RNA positive and those who were HCV-RNA negative or between the different genotypes. Participants were recruited using respondentdriven sampling method. The blood samples were collected as dried blood spots and then eluted to be tested for HCV, HBV and HIV by ELISA. Anti-HCV positive samples were subjected to RNA extraction followed by qualitative detection and genotyping.

Results: Among 106 IDUs, 56 (52.8\%) were anti-HCV-positive. The two groups did not differ in terms of age, marital status, and nationality. As for the behavioral variable, there was a trend of increased risky behaviors among the HCVRNA positive group as compared to the HCV-RNA negative group but none of the variables reached statistical significance. Half (50\%) of the 56 anti-HCV-positive were HCV-RNA positive. Genotype 3 was the predominant one (57.1\%) followed by genotype 1 (21\%) and genotype 4 (18\%).

Conclusions: The predominance of genotype 3 seems to be the predominant genotype among IDUs in Lebanon, a situation similar to that among IDUs in Western Europe. This study provides a base-line against possible future radical epidemiological variant that might occur in IDUs.
\end{abstract}

\section{Background}

The prevalence of $\mathrm{HCV}$ antibody (anti-HCV) among intravenous drug users (IVDUs) who share injecting equipment exceeds $50 \%[1,2]$. This has now become a critical public health threat [3]. The lack of availability of an effective vaccine allowed education programs to be the most suitable interventions in the control of $\mathrm{HCV}$ spread $[4,5]$.

Hepatitis $C$ virus has been classified into 6 major genotypes (1-6) and into several subtypes (a, b, c etc) [6] and additional genotypes have been recently proposed $[7,8]$. The genotypes have a geographically distinct distribution $[9,10]$ which carries important implications such as treatment decisions, possible transmission route and vaccine development. For example the response to therapy observed in patients infected with genotypes 1 and 4 is lower than that infected with genotypes 2 and $3[11,12]$.

* Correspondence: sramia@live.com

${ }^{3}$ Department Medical Laboratory Sciences, Faculty of Health Sciences, American University of Beirut, Beirut, Lebanon

Full list of author information is available at the end of the article
Genotype 3a was shown to be more common in Europe among young injecting drug users, compared to genotype $1 \mathrm{~b}$ which is associated with transfusion-related $\mathrm{HCV}$ [13]. Recently we have shown genotype 4 to be the predominant genotype among HCV-infected Lebanese patients $(34.2 \%-53.3 \%)[10]$.

The aim of this study is to determine the prevalence of anti-HCV among injecting drug users (IDUs) in Lebanon, to establish the current prevalence of HCV genotypes in this population and to determine whether demographic characteristics and behavioral variables differ between participants who were HCV-RNA positive and those who were HCV-RNA negative or between the different genotypes.

\section{Methods \\ Study Population and Sampling Methods}

Participants included in this study were part of a biobehavioral surveillance study done to assess HIV prevalence among four vulnerable groups (men who have sex with men, injecting drug users, female sex workers, and 
prisoners). Two well established Lebanese non-governmental organizations (NGOs) that work with IDUs helped in the study.

Participants in this study were recruited using a relatively new technique entitled respondent-driven sampling (RDS) that has been shown to be effective in reaching difficult to reach or invisible populations for which there is not sampling-frame [14]. A total of 106 eligible IDUs participated in the main study and all were males. After obtaining informed consent, participants completed the questionnaire and an HIV rapid test were offered in addition to proper pretest and post test counseling.

\section{Laboratory Methods Sample collection}

Peripheral blood was collected by a finger prick with a single use Lancet and then blotted onto a high quality filter paper (Schleicher \& Schuell 903). The blood spot was allowed to air dry to be used as a dried blood spot (DBS) for further testing at the Molecular Biology Research Laboratory at the Faculty of Health Sciences, American University of Beirut (AUB).

\section{Elution procedure}

For each serological test, one DBS disc was cut and placed in the well of a flat-bottomed uncoated micro plate. The blood was then eluted as described previously by Parker and Gublit [15].

\section{Anti-HCV detection and RNA extraction}

Eluates were tested for anti-HCV by ELISA using a modified protocol for Ortho HCV 3.0 SAVe (Ortho Clinical Diagnostics, Johnson \& Johnson). Anti-HCV positive DBS samples were then subjected to RNA extraction using QIAamp MiniElute Virus Spin (QIAGEN) for further qualitative $\mathrm{HCV}$ detection and genotyping.

\section{$\mathrm{HCV}$ qualitative detection and HCV genotyping}

COBAS AMPLICOR Hepatitis C Virus Test, version 2.0 (v2.0) was used for qualitative in vitro diagnostic HCV detection in the RNA extracted samples using COBAS AMPLICOR Analyzer (Roche). Qualitatively positive $\mathrm{HCV}$ aliquots of denatured amplicon by Cobas Amplicor were genotyped using a single LINEAR ARRAY HCV Genotyping strip (LINEAR ARRAY Hepatitis C Virus Genotyping Test - Roche) which is coated with a series of oligonucleotide probes specific for various HCV genotypes.

\section{Statistical Analysis}

Descriptive statistics including means and standard deviation and frequency distributions were computed for demographic variables and behavioral variables. Comparisons between HCV-RNA positive and HCV-RNA negative groups were performed using the Chi-squared test for categorical variables (for examples, Sharing needles, marital status, imprisonment, and having a tattoo) and ttest for continuous variables (for example age). Significance was set at the $5 \%$ level. All analysis were done using SPSS version 16.0 (Chicago, Illinois, USA).

\section{Results}

Only 28 (50\%) of the 56 anti-HCV-positive were HCVRNA positive. Characteristics and behaviors of those who were HCV-RNA positive and HCV-RNA negative are summarized in Table 1. The average age of the participants was 40 years. Almost all participant were Lebanese (96\%) and a high proportion of them were ever married (61\%). The two groups did not differ in terms of age, marital status, and nationality. As for the behavioral variable, there was a trend of increased risky behaviors (such as having tattoos, sharing needles and injecting drugs in prison) among the HCV-RNA positive group as compared to the HCV-RNA negative group but none of the variables reached statistical significance.

\section{HCV Genotype Distribution}

Only HCV genotypes 1, 3 and 4 were detected and one sample showed mixed genotype (1 and 3). The distribution of genotypes is shown in Table 2. Genotype 3 was the predominant (57\%) followed by genotype $1(21 \%)$ and genotype 4 (18\%).

Characteristics of the HCV RNA-positive sample population $(\mathrm{n}=28)$ according to their genotype is shown in Table 3. The one person with a mixed genotype was not included since no replication is available for comparison reasons.

\section{Discussion}

HCV-RNA positivity (50\%) detected in our anti-HCVpositive IDUs patients is in agreement with similar studies from different parts of the world including Europe[2,16], North America[17] and Australia [18]. It has been recently reported that a statistically significant linear relationship could be observed between the mean age and the prevalence of HCV-RNA in IDUs [19]. This linearity however could not be confirmed in our study since most of our studied subjects were relatively young adults and experienced their first injection within roughly the same period of time.

The distribution of $\mathrm{HCV}$ genotypes in our IDUs showed that HCV genotype 3 was the predominant genotype $(57.1 \%)$ followed by genotype $1(21.4 \%)$ and genotype $4(17.9 \%)$. This was surprising and in contrast with our earlier findings where genotype 4 was the predominant genotype (47.5\%) in Lebanese patients [10]. The strength of our current data compared to the aforementioned one is that IDUs were recruited in this study by a novel technique (RDS) and that they were from different regions of the country while the earlier study was hospi- 
Table 1: Comparing Characteristics and behaviors of those who were HCV-RNA positive to those who were HCV-RNA negative

\begin{tabular}{|c|c|c|c|}
\hline \multirow[b]{2}{*}{ Variable } & \multicolumn{3}{|c|}{ HCV RNA } \\
\hline & $\begin{array}{l}\text { Positive } \\
(n=28)\end{array}$ & $\begin{array}{l}\text { Negative } \\
(n=28)\end{array}$ & p-value \\
\hline \multicolumn{4}{|l|}{ Demographic } \\
\hline \multicolumn{4}{|l|}{ • Age (in years) } \\
\hline- Mean \pm st dev & $40 \pm 11$ & $40 \pm 13$ & .98 \\
\hline - Median (min-max) & $38(21-67)$ & $40(21-63)$ & \\
\hline - Marital Status & & & .51 \\
\hline - Married & $10(36 \%)$ & $6(21 \%)$ & \\
\hline - Divorced & $4(14 \%)$ & $8(29 \%)$ & \\
\hline - Separated & $3(11 \%)$ & $3(11 \%)$ & \\
\hline - Single & $11(39 \%)$ & $11(39 \%)$ & \\
\hline - Lebanese Nationality & $26(93 \%)$ & $27(96 \%)$ & $>.99$ \\
\hline \multicolumn{4}{|l|}{ Injecting Risk Behavior } \\
\hline $\begin{array}{l}\text { - Ever sharing injecting } \\
\text { equipments }\end{array}$ & $12(43 \%)$ & $9(32 \%)$ & .41 \\
\hline \multicolumn{4}{|l|}{$\begin{array}{l}\text { - Age first injecting drug } \\
\text { use }\end{array}$} \\
\hline- Mean \pm st dev & $28 \pm 11$ & $28 \pm 9$ & $>.99$ \\
\hline - Median (min-max) & $25(14-59)$ & $26(14-53)$ & \\
\hline Ever Imprisonment & $28(100 \%)$ & $26(93 \%)$ & $>.99$ \\
\hline Injecting while in prison & $4(14 \%)$ & $2(8 \%)$ & .44 \\
\hline Tattoo & $24(86 \%)$ & $19(68 \%)$ & .11 \\
\hline
\end{tabular}

Table 2: Distribution of HCV Genotypes among Injecting Drug users (IDUs) in Lebanon

\begin{tabular}{|c|c|c|}
\hline Genotype & Number & $\%$ \\
\hline Genotype I & 6 & 21 \\
\hline Genotype 2 & 0 & 0 \\
\hline Genotype 3 & 16 & 57 \\
\hline Genotype 4 & 5 & 18 \\
\hline Genotype 5 & 0 & 0 \\
\hline Genotype 6 & 0 & 0 \\
\hline Mixed genotype (1/3) & 1 & 4 \\
\hline TOTAL & 28 & 100 \\
\hline
\end{tabular}


Table 3: Characteristics of the HCV RNA positive sample population according to their genotypes

\begin{tabular}{|c|c|c|c|}
\hline \multirow[b]{2}{*}{ Patient Characteristic } & \multicolumn{3}{|c|}{ HCV Genotypes } \\
\hline & $\begin{array}{l}1(n=6) \\
N \%\end{array}$ & $\begin{array}{l}3(n=16) \\
N \%\end{array}$ & $\begin{array}{l}4(n=5) \\
N \%\end{array}$ \\
\hline \multicolumn{4}{|l|}{ Demographic } \\
\hline - Age (in years) & $44 \pm 9$ & $40 \pm 13$ & $38 \pm 10$ \\
\hline- Mean \pm st dev & $40(36-60)$ & $37(21-67)$ & $35(26-51)$ \\
\hline \multicolumn{4}{|l|}{ - Median (min-max) } \\
\hline \multicolumn{4}{|l|}{ - Marital Status } \\
\hline - Married & $3(50 \%)$ & $5(31 \%)$ & $2(40 \%)$ \\
\hline - Divorced & $1(17 \%)$ & $1(6 \%)$ & $2(40 \%)$ \\
\hline - Separated & $0(0 \%)$ & $3(19 \%)$ & $0(0 \%)$ \\
\hline - Single & $2(33 \%)$ & $7(44 \%)$ & $1(20 \%)$ \\
\hline - Lebanese Nationality & $4(67 \%)$ & $16(100 \%)$ & $5(100 \%)$ \\
\hline \multicolumn{4}{|l|}{ Injecting Risk Behavior } \\
\hline $\begin{array}{l}\text { - Ever sharing injecting } \\
\text { equipments }\end{array}$ & $3(50 \%)$ & $5(31 \%)$ & $4(80 \%)$ \\
\hline \multicolumn{4}{|l|}{$\begin{array}{l}\text { - Age first injecting drug } \\
\text { use }\end{array}$} \\
\hline - Mean \pm st dev & $31 \pm 16$ & $29 \pm 10$ & $25 \pm 13$ \\
\hline - Median (min-max) & $28(17-59)$ & $26(14-52)$ & $20(17-47)$ \\
\hline Ever Imprisonment & $6(100 \%)$ & $16(100 \%)$ & $5(100 \%)$ \\
\hline Injecting while in prison & $1(17 \%)$ & $2(13 \%)$ & $1(20 \%)$ \\
\hline Tattoo & $4(67 \%)$ & $14(88 \%)$ & $5(100 \%)$ \\
\hline
\end{tabular}

tal-based. The predominance of genotype 3 makes the situation in Lebanon similar to that among IDUs in Europe $[2,16]$ and points to the possibility that genotype 3 could have been introduced to our IDUs Population from Europe. One of the limitations of the study is that the questionnaire did not address socio-economic factors such as income, education and mobility among others.

Since IDUs become infected with $\mathrm{HCV}$ in the early phases of drug addiction and most become exposed repeatedly to the virus through needle-sharing, it is expected that infection with more than one genotype would be common [20]. Mixed infections of genotypes were detected in only one sample in our study (3.6\%). The higher incidence of mixed infections reported by others could possibly be due to the older age of IDUs in these studies and hence more multiple exposures to $\mathrm{HCV}$ infection by sharing of injection material.

Data on major HCV genotypes circulating among injecting drug users in neighboring Middle Eastern countries is still limited [21,22]. This information would be of importance in contributing to a regional network for the surveillance of HCV genotypes in Middle Eastern countries, an information that could have epidemiological significance. Furthermore, our data might also have therapeutic implications. It has been reported that the response to therapy in patients infected with genotypes 1 and 4 is lower than that noticed in patients infected with genotypes 2 and $3[11,12]$. It is believed that appropriate treatment may play a role in containing the $\mathrm{HCV}$ epidemic that is now being described in IDUs all over the world.

\section{Conclusions}

Despite the small number of patients investigated, it can be concluded that genotype 3 seems to be the predominant genotype among IDUs in Lebanon, a situation similar to that among IDUs in Western Europe. However, the authors would like to acknowledge that the sample method used (RDS) was not random as is the situation for population-based surveys such as the National Health and the Examination Survey and thus our findings may or may not be representative of the entire population of 
IDUs in Lebanon. This study provides a base-line against possible future radical epidemiological variant that might occur in IDUs.

\section{Competing interests}

The authors declare that they have no competing interests.

\section{Authors' contributions}

ZM have made contributions to acquisition, analysis and interpretation of data. $\mathrm{KK}^{2}$ designed the study. $\mathrm{KK}^{3}$ carried out the laboratory tests and have been involved in drafting the manuscript and revising its content. SS performed the laboratory tests. SR was responsible for drafting and finalizing the manuscript and has given final approval of the version to be published. All authors read and approved the final version.

\section{Acknowledgements}

We would like to thank the National AIDS Control Programme, Ministry of Public Health, Lebanon, who supported the study, and who through the World Bank Group, provided funds under the IDF Grant for Strengthening the National HIV/AIDS Monitoring and Evaluation and Surveillance Systems in Lebanon. We specifically thank Dr. Mostafa El Nakib, Program Manager NAP-MOPH, for his continuous input and support.

We gratefully acknowledge Dr. David Wilson, Lead Health Specialist-World Bank and Dr. Francisca Ayo Akala, Senior Public Health Specialist-World Bank for substantive comments and support.

The study would not have been possible without the cooperation of the Lebanese NGOs involved as members of the research team Oum El Nour (Mother of Light) and Skoun (Stillness). We thank all team members at these NGOs and other team members at the American University of Beirut.

We would like to thank all those who participated in the study for their time, efforts and willingness to address sensitive topics. The authors would like to acknowledge Roche Diagnostics and all those who helped in supporting the implementation of the study: Miss Danielle El-Khoury (Study Coordinator), Miss Farah El-Barbir and Miss Maguy Ghanem (Research Assistants), and Ms. Maha Abul Naja (Secretary).

\section{Author Details}

'Department of Epidemiology and Population Health, Faculty of Health Sciences, American University of Beirut, Beirut, Lebanon, ${ }^{2}$ Department of Health Management and Policy, Faculty of Health Sciences, American University of Beirut, Beirut, Lebanon and ${ }^{3}$ Department Medical Laboratory Sciences, Faculty of Health Sciences, American University of Beirut, Beirut, Lebanon

Received: 10 March 2010 Accepted: 13 May 2010 Published: 13 May 2010

\section{References}

1. Lucidarme D, Decoster A, Fremaux D, Harbonnier J, Jacob C, Vosgien V, Josse P, Villeger P, Henrio C, Prouvost-Keller B, Saccardy C, Lemaire M, Vazeille G, Duchene C, Thuillier M, Colbeaux C, Lefebvre AM, Forzy G, Filoche B: Routine practice HCV infection screening with saliva samples: multicentric study in an intravenous drug user population. Gastroenterology and Clinical Biology 2007, 31:480-484.

2. Micalessi M, Gerard C, Ameye L, Plasschaert S, Brochier B, Vranckx R: Distribution of hepatitis $C$ virus genotypes among injecting drug users in contract with treatment centers in Belgium 2004-2005. Journal of Medical Virology 2008, 80:640-645.

3. Pybus O, Cochrane A, Holmes E, Simmonds P: The hepatitis C virus epidemic among injecting drug users, Infection. Genetics and Evolution 2005, 5:131-139.

4. Taylor A, Goldberg D, Hutchinson S, Cameron S, Gore SM, McMenamin J, Green S, Pithie A, Fox R: Prevalence of hepatitis C virus infection among injecting drug users in Glasgow 1990-1996: are current harm reduction strategies working? Journal of Infection 2000, 40:176-183.

5. Goldberg D, Burns S, Taylor A, Cameron S, Hargreavas D, Hutchison S: Trends in HCV prevalence among injecting drug users in Glasgow and Edinburgh during the era of needle exchange. Scandinavian Journal Infectious Diseases 2001, 33:457-461.
6. de Lamballerie X, Charrel RN, Attoui H, De Miccop: Classification of hepatitis $C$ virus variants in six major types based on analysis of the envelop 1 and non-structural 5B genome regions and complete polyprotein sequences. Journal of General Virology 1997, 78:45-51.

7. Tokita $\mathrm{H}$, Okamoto $\mathrm{H}$, Luengrojanakul $\mathrm{P}$, Vareesangthip K, Chainuvati T, lizuka H, Tsuda F, Miyakawa Y, Mayumi M: Hepatitis C virus variants from Thailand classifiable into five novel genotypes in the sixth (6b), seventh $(7 c, 7 d)$ and ninth $(9 b, 9 c)$ major genetic groups. Journal of General Virology 1995, 76:2329-2335.

8. Tokita H, Okamoto H, lizuka H, Kishimoto J, Tsuda F, Lesmana LA, Miyakawa Y, Mayumi M: Hepatitis C virus variants from Jakarta, Indonesia, classifiable into novel genotypes in the second (2e and 2f) tenth (10a) and eleventh (11a) genetic groups. Journal of General Virology 1996, 77:293-301

9. Simmonds P: Variability of the hepatitis $C$ genome. In Hepatitis $C$ virus Edited by: Reesink HW. Karger, Basel; 1998.

10. Sharara A, Ramia S, Ramlawi F, Eid-Fares J, Klayme S, Naman R: Genotypes of hepatitis $C$ virus (HCV) among positive Lebanese patients: comparison of data with that from other Middle Eastern countries. Epidemiology and Infection 2007, 135:427-432

11. Kurbanov F, Tanaka Y, Sugauchi F, Kato H, Ruzibakiev R, Zalyalieva M, Yunusova Z, Mizokami M: Hepatitis C virus molecular epidemiology in Uzbekistan. Journal of Medical Virology 2003, 69:367-375.

12. Poynard T, Yuen MF, Ratziu V, Lai CL: Viral hepatitis C. Lancet 2004, 362:2095-2100

13. Pawlotsky JM, Tsakiris L, Roudot-Thoraval F, Pellet C, Stuyver L, Duval J, Dhumeaux D: Relationship between hepatitis $C$ virus genotypes and sources of infection in patients with chronic hepatitis C. Journal of Infectious Diseases 1995, 171:1607-1610.

14. Heckathorn DD: Respondent-driven sampling: A new approach to the study of hidden populations. Social Problems 1997, 44:174-199.

15. Parker SP, Gubilt WD: The use of the dried blood spot sample in epidemiological studies. J Clinical Pathology 1999, 52:633-639.

16. Mathei C, Wollants E, Verbeeck J, Van Ranst M, Robaeys G, Van Damme P, Buntinx F: Molecular epidemiology of hepatitis $C$ among drug users in Flanders, Belgium: association of genotypes with clinical parameters with sex and drug- related risk behaviors. European Journal Clinical Microbiology and Infectious Diseases 2005, 24:514-522.

17. Lauer GM, Walker BD: Hepatitis C virus infection. New England Journal of Medicine 2001, 345:41-52.

18. Freeman AJ, Zekry A, Whybin $L R$, Harvey $C E$, van Beek IA, de Kantzow SL, Rawlinson WD, Boughton CR, Robertson PW, Marinos G, Lloyd AR: Hepatitis $\mathrm{C}$ prevalence among Australian injecting drug users in the 1970 s and profiles of virus genotypes in the 1970s and 1990s. Medical Journal of Australia 2000, 172:588-591.

19. Mathei $C$, Buntinx $F$, Van Damme $P$ : Is the prevalence of hepatitis $C$ virus (HCV) RNA in an anti-HCV-positive injection drug users positively correlated with age? Journal of Infectious Diseases 2001, 184:659-660.

20. Silini E, Bono F, Cividini A, Cerino A, Maccabruni A, Tinelli C, Bruno S, Bellobuono A, Mondelli M: Molecular epidemiology of hepatitis C virus infection among intravenous drug users. Journal of Hepatology 1995, 22:691-695

21. Zamani S, Ichikawa S, Nassirimanesh B, Vazirian M, Ichikawa K, Gouya MM, Afshar P, Ono-Kihara M, Ravari SM, Kihara M: Prevalence and correlates of hepatitis $C$ virus infection among injecting drug users in Tehran. International Journal of Drug Policy 2007, 18:359-563.

22. Alzahrani AJ: Simultaneous detection of hepatitis $C$ virus core antigen and antibodies in Saudi drug users using a novel assay. Journal of Medical Virology 2008, 80:603-606.

doi: 10.1186/1743-422X-7-96

Cite this article as: Mahfoud et al., Distribution of hepatitis C virus genotypes among injecting drug users in Lebanon Virology Journal 2010, 7:96 